logos_i_ethos_2019_1_(49), s. 45-64

DOI: http://dx.doi.org/10.15633/lie.3434

Lech Wołowski

https://orcid.org/0000-0003-2012-1267

Uniwersytet Papieski Jana Pawła II w Krakowie

\title{
Agatologiczne implikacje paradoksu „walki transcendentaliów" u Hansa Ursa von Balthasara i Józefa Tischnera
}

\section{Problem „walki transcendentaliów”}

Zagadnienie transcendentaliów ${ }^{1}$ przewija się często w myśli Hansa Ursa von Balthasara i Józefa Tischnera. Można powiedzieć, że studium nad pięknem, dobrem i prawdą stało się wspólną podstawą ich refleksji filozoficzno-teologicznej ${ }^{2}$. ks. dr Lech Wołowski - pracownik dydaktyczno-naukowy Instytutu Dogmatyki Wydziału Teologii Uniwersytetu Papieskiego Jana Pawła II. W 2017 roku obronił pracę doktorską na Uniwersytecie Gregoriańskim w Rzymie zatytułowaną: La grazia e la libertà nel dramma dell'uomo bisognoso della salvez$z a$ in H. U. von Balthasar e J. Tischner. Oprócz zagadnień z zakresu teologii dogmatycznej do jego zainteresowań należy twórczość J. Tischnera, zwłaszcza agatologia i zagadnienia dramatu oraz pogranicze teologiczno-filozoficzne myśli H. U. von Balthasara.

1 Przez „transcendentalia” będziemy rozumieć triadę złożoną z piękna, dobra i prawdy. W zależności jednak od kontekstu i cytowanego autora triadę tę poprzedza często byt, a niejednokrotnie dochodzi też i jedność. Ta niejednoznaczność klasyfikacji transcendentaliów nie będzie jednak przedmiotem naszej uwagi, gdyż docelowo skoncentrujemy się tylko na jednym z nich, tj. na dobru.

2 To, że swoje koronne dzieło, czyli Trylogię (złożoną z Estetyki, Teodramatyki i Teologiki), Balthasar świadomie opiera na klasycznej triadzie transcendentaliów, potwierdza on osobiście w Epilogu do tego dzieła: „teologia oparta na traktatach czy topice teologicznej została tu przedstawiona zupełnie inaczej, a mianowicie z perspektywy transcendentaliów" (H. U. von Balthasar, Epilog, tłum. J. Zychowicz, Kraków 2010, s. 7). W kwestii ogólnego podejścia Balthasara do transcendentaliów warto skonsultować prace: M. Saint-Pierre, Beauté, bonté, vérité, chez Hans Urs von Balthasar, Paris 1998; J. O’Donnell, Klucz do teologii Hansa Ursa von Balthasara, Kraków 2005, passim. W przypadku Tischnera wystarczy nadmienić, że centralny, trzeci rozdział swojej Filozofii dramatu poświęca on refleksji nad trzema żywiołami odpowiadającymi tym samym trzem 
Różni ich natomiast inne spojrzenie na rolę, jaką transcendentalia mają pełnić w filozofii i teologii oraz na charakter wzajemnych relacji, jakie zachodzą pomiędzy elementami transcendentalnej triady.

Podstawowym problemem, $\mathrm{z}$ jakim zamierzamy zmierzyć się w tym artykule, jest kwestia rozumienia, w ujęciu obu autorów, równorzędności czy równoważności ${ }^{3}$ transcendentaliów lub też przeciwnie - jej braku, przejawiającego się w zjawisku „walki” między nimi. Szczególny nacisk położony będzie na kwestię dobra jako transcendentale, na przykładzie którego najwyraźniej rysuje się różnica w poglądach obu myślicieli i najdonioślejsze wydają się być tego konsekwencje.

Zarysowując historyczne tło przedstawionego problemu, należy stwierdzić, że w filozofii średniowiecznej ugruntował się reprezentowany przez Tomasza $\mathrm{z}$ Akwinu pogląd o całkowitej konwertybilności transcendentaliów, co znalazło swój wyraz w maksymie: ens, pulchrum, verum et bonum - convertuntur ${ }^{4}$. Opinia ta, przyjmowana niemal za aksjomat, przeniknęła do tego stopnia do świadomości nie tylko filozoficznej, ale także i powszechnej, że rzadko który znany myśliciel, nie tylko średniowieczny, ale również nowożytny, podejmował się próby poważnej polemiki w tym zakresie. Tischner wyraźnie zauważa i w charakterystyczny dla siebie sposób opisuje zarysowany tu stan rzeczy:

transcendentaliom: Błądzenie $w$ żywiole piękna. Błądzenie $w$ żywiole prawdy. Błądzenie $w \dot{z} y w i o l e$ dobra (J. Tischner, Filozofia dramatu, Kraków 2012, s. 111-264). W kwestii refleksji Tischnera nad transcendentaliami, zwłaszcza nad najważniejszą dla nas agatologią, zob. A. Bobko, Myślenie wobec zła, Kraków-Rzeszów 2007, passim.

3 Oprócz stosowanych tu zamiennie ( $w$ tym kontekście) terminów „równorzędność” i „równoważność”, w literaturze przedmiotu spotkać można także następujące określenia: „konwertybilność” (od łac. convertere), „równozakresowość”, „zamienność”, „przekładalność” itp.

4 Do maksymy tej, w takiej formie, odwołuje się Tischner (J. Tischner, Filozofia dramatu, dz. cyt., s. 50). Tomasz, w swym oryginalnym sformułowaniu, pomija piękno. Nie wchodzimy tu jednak ani w szczegóły tomistycznej teorii transcendentaliów, ani w kwestię motywów pominięcia w niej piękna. Zainteresowanego czytelnika odsyłamy do pracy: J. Kiełbasa, Pierwsze i najpowszechniejsze: jedność, prawda, dobro i inne transcendentalia w metafizyce św. Tomasza z Akwinu, „Przegląd Tomistyczny" 19 (2013), passim. 
Scholastyczna teoria tak zwanych transcendentaliów głosiła, że ens, pulchrum, verum et bonum - convertuntur. W świetle tej koncepcji niemożliwe byłoby całkiem rozdzielne traktowanie teorii bytu, prawdy i dobra oraz piękna. Pociągało to za sobą określony sposób rozumienia metafizyki: ontologia bytu była zarazem metafizyką bytu, a metafizyka była ontologią prawy i dobra, i - jeśli ktoś chciał - piękna. Założenia tego nie naruszył ani Hegel, ani Heidegger, chociaż przyjęli oni inną koncepcję bytu, respective bycia ${ }^{5}$.

Krakowski myśliciel zauważa jednak, że najwyższy już czas dostrzec w dziedzinie transcendentaliów swego rodzaju paradoks „sporu”, czy też „walki”, jaka toczy się między nimi. Formułuje on ten paradoks postaci następującej serii pytań:

czy byt jest bytem naprawdę czy tylko pozorem bytu? Czy piękno odsłania przed nami prawdę świata, czy karmi nas samym kłamstwem? Czy to, co jawi się jako dobre, jest dobre naprawdę? Czy prawda jest prawdą także wtedy, gdy nas unieszczęśliwia? Czy lepiej jest żyć wśród uszczęśliwiających kłamstw czy prawd przynoszących nieszczęście?

Jak już wyżej wspomnieliśmy, w opinii powszechnej, transcendentalia pozostają w pełnej równowadze, tymczasem, jak zauważa Tischner, w życiu codziennym obserwujemy ich ciągłą walkę. Mamy więc tu do czynienia z sytuacją, kiedy obserwowane przez nas zjawisko zdaje się przeczyć ugruntowanemu w nas powszechnemu mniemaniu. Sytuację taką nazywamy paradoksem ${ }^{7}$. W tym przypadku będziemy mówić o paradoksie „walki transcendentaliów”.

5 J. Tischner, Filozofia dramatu, dz. cyt., s. 50.

6 J. Tischner, Filozofia dramatu, dz. cyt., s. 51.

7 Warto podkreślić, że mamy tu do czynienia nie z absurdem i nie ze sprzecznością, tylko właśnie z paradoksem. W języku potocznym pojęcia te niestety często są mylone i stosowane zamiennie. Tymczasem paradoks oznacza nie tyle sprzeczność samą w sobie (a tym bardziej nie absurd), lecz twierdzenie sprzeczne z powszechnym mniemaniem lub - co najwyżej - sprzeczność pozorną. Por. np. Paradoks 1, https://sjp.pwn.pl/szukaj/paradoks.html (25.08.2019). 
Należy tu od razu dodać, że paradoks ten dostrzeżony został również przez Balthasara, choć trzeba jednocześnie przyznać, iż szwajcarski teolog był dużo ostrożniejszy od Tischnera w swoich sformułowaniach w tym zakresie. Wygląda na to, że Balthasar stał nieco na rozdrożu w tej kwestii. Z jednej strony, mimo że przez niektórych autorów postrzegany był jako adwersarz tomizmu, zwłaszcza w jego neoscholastycznym wydaniu $^{8}$, w tym akurat przypadku deklarował się jako całkowity zwolennik tomistycznej maksymy zamienności:

Jeśli prawda i dobro są rzeczywiście dwiema transcendentalnymi cechami bytu, to muszą się one wzajemnie przenikać, każde zaś wykluczające przeciwstawianie ich dziedzin może prowadzić tylko do zapoznania istoty każdego $\mathrm{z}$ nich. To samo dotyczy też odpowiednio ostatniej transcendentalnej cechy bytu - piękna: również ono rości sobie prawdo do powszechnej aktualności, również jego zatem nie można nigdy oddzielać od obu jego sióstr9?

Z drugiej strony, nie ulega wątpliwości, że również i on był głęboko świadomy opisanego wyżej zjawiska „walki”. Najwyraźniej widać to, kiedy konfrontuje on swoje estetyczne rozważania z pierwszej części Trylogii $\mathrm{z}$ agatologiczno-dramatycznymi refleksjami zawartymi $\mathrm{w}$ jej drugiej części:

Chwała Boga w świecie, która objawia się jako w swym centrum w Chrystusie, nie jest czymś statycznym, poddającym się neutralnej kontemplacji. Ona sama manifestuje się w zaangażowaniu w walkę, w zwycięstwo i w porażkę, i domaga się

8 Do adwersarzy neoscholastycznej wersji tomizmu zaliczyli Balthasara m.in. Canobbio i Coda (zob. La teologia del XX secolo: un bilancio, t. 1: Prospettive storiche, a cura di G. Canobbio, P. Coda, Roma 2003, s. 63). Należy tu jednak zaznaczyć, iż Balthasar wyraźnie odróżniał myśl samego Tomasza (z którą częściowo sympatyzował, a częściowo polemizował) od podglądów prezentowanych przez różne nurty tomistyczne, zwłaszcza nurt neoscholastyczny. Czytelnika zainteresowanego zdaniem samego Balthasara w tej kwestii odnosimy do pracy: H. U. von Balthasar, Theologie und Heiligkeit, Theologie und Heiligkeit, w: Verbum Caro. Skizzen zur Theologie, Bd.1, Einsiedeln 1990, passim.

9 H. U. von Balthasar, Teologika, t. 1: Prawda świata, tłum. J. Zychowicz, Kraków 2004, s. 30. 
analogicznego zaangażowania, kiedy tylko wejdzie się w jej pole widzenia. Objawienie jest polem walki ${ }^{10}$.

Wyrażenie „walka transcendentaliów” nie pada wprawdzie explicite $\mathrm{z}$ ust Balthasara, mamy tu jednak do czynienia $\mathrm{z}$ walką (przeniesioną z pola filozoficznego na teologiczne) pomiędzy estetyką (piękno) chwały Bożej, a dramatem (dobro) życia ludzkiego.

\section{2. „Dyskusja” Balthasara i Tischnera w kwestii „walki transcendentaliów”}

Tischner i Balthasar nie mieli okazji spotkać się osobiście, nie nawiązali też nigdy dyskusji korespondencyjnej, niemniej jednak, w nieco odmiennych kontekstach i niemal całkowicie niezależnie od siebie ${ }^{11}$, podjęli problem „walki transcendentaliów” w sposób na tyle spójny, że dziś, bazując na ich tekstach, możemy pokusić się o swego rodzaju wirtualną rekonstrukcję ich „dyskusji” w tym temacie.

Dyskusję tę rozpocząć należy od - inspirowanej myślą Franza Rosenzweiga - krytyki, jaką wysunął Tischner wobec niekwestionowanego przez bardzo długi czas tomistycznego prawa równoważności transcendentaliów, a w szczególności obowiązującej w ramach tego prawa równorzędności bytu i dobra. Dla Tischnera „oznaczało to w każdym przypadku jakąś formę ontologizacji metafizyki” i dlatego, wcześniej czy później, „ujęcie takie znalazło jednak krytyków”" ${ }^{12}$ Tischner dołącza do grona tych krytyków z wielkim zapałem, wyjawiając, przy okazji, podstawowe inspiracje, jakie krytykom tego prawa przyświecały:

10 H. U. von Balthasar, Theodramatik, Bd. 3: Die Handlung, Einsiedeln 1980, s. 12, [tł. wł.] Uwaga: w niniejszej pracy, tam gdzie dostępne są polskie tłumaczenia dzieł Balthasara, cytujemy te tłumaczenia. W przeciwnym razie, podajemy tłumaczenie własne [tł. wł.] wraz z odnośnikiem do niemieckojęzycznego oryginału.

11 Kwestię niezależności myśli Balthasara i Tischnera rozpatrujemy szczegółowo w osobnym artykule.

12 J. Tischner, Filozofia dramatu, dz. cyt., s. 50. 
Najostrzej wystąpił przeciwko niemu - mając na względzie filozofię Hegla Rosenzweig. Inspirowane Biblią myślenie Rosenzweiga nie daje się już zamknąć $\mathrm{w}$ opisie utkanym z pojęć wywiedzionych $\mathrm{z}$ idei bytu lub bycia. Myślenie to czuje się wezwane, by myśleć dramat człowieka - dramat, na który składa się wydarzenie stworzenia, objawienia (wybrania) i zbawienia. Jedynie pierwsze wydarzenie pozwala na to, by je opisać w kategoriach ontologii, natomiast inne - objawienie czy zbawienie - nie dopuszczają tej możliwości ${ }^{13}$.

Krakowski filozof zauważa, iż podejście ontologiczne, stawiające byt, piękno, prawdę i dobro na jednym poziomie, być może sprawdza się w opisie relacji międzyprzedmiotowych, zachodzących na „scenie dramatu", a także intencjonalnych, tj. zachodzących na linii człowiek-przedmiot $^{14}$. Podejście to nie jest jednak w stanie posłużyć do wychwycenia subtelności, czy też do zgłębienia tajemnic, jakie kryją się w relacjach dramatycznych zachodzących między ludźmi lub między człowiekiem a Bogiem. Do opisu tych ostatnich trzeba odwołać się do podejścia personalno-agatologicznego, zapoczątkowanego przez Rosenzweiga i rozwiniętego przez Emmanuela Lévinasa:

Aby pojąć istotny dramat człowieka, nie wystarczy zgłębić tajemnicę samej sceny, lecz trzeba sięgnąć do kategorii, które są poza bytem i niebytem, które ukazują coś, co jest inaczej niż bycie - co nie jest „sposobem bycia”. Lévinas idzie śladem tej samej krytyki, ale jego przeciwnikiem filozoficznym jest bardziej Heidegger niż Hegel ${ }^{15}$.

Propozycja Lévinasa polega na uznaniu z podstawową nie kategorię bytu czy bycia, lecz kategorię dobra ${ }^{16}$. Idąc za Lévinasem, Tischner

13 J. Tischner, Filozofia dramatu, dz. cyt., s. 50.

14 Istotę relacji intencjonalnych opisuje Tischner w następujący sposób: „Pojęcie intencjonalności pochodzi od Husserla. Intencjonalne są akty świadomości. Oznacza to, że są one z istoty swej skierowane na jakiś przedmiot. Kto jednak mówi o przedmiocie, myśli tym samym o podmiocie; nie może być przedmiotu bez podmiotu ani podmiotu bez przedmiotu" (J. Tischner, Filozofia dramatu, dz. cyt., s. 12).

15 J. Tischner, Filozofia dramatu, dz. cyt., s. 50.

16 Terminu „kategoria” nie używamy - podobnie jak Tischner w przytoczonych cytatach - w specyficznym znaczeniu arystotelesowskim czy kantowskim, lecz w ogólnym sensie klasyfikacyjnym. 
proponuje nowe podejście do metafizyki: podejście agatologiczne, które ma zastąpić stare, niewytrzymujące już współczesnej krytyki, podejście ontologiczne:

Otóż, zdaniem Lévinasa, nieskończona doskonałość nie daje się opisać za pomocą kategorii bycia, respsecitve bytu. Trzeba posłużyć się ideą dobra. W miarę jak Lévinas uświadamia sobie tę niemożliwość, jego metafizyka staje się coraz wyraźniej metafizyką czegoś wyższego niż byt - metafizyką dobra ${ }^{17}$.

Zaproponowana przez Tischnera zasada odróżniająca poziom ontologiczny do wyższego od niego poziomu agatologicznego będzie nazywana przez nas „zasadą agatologiczną”.

Balthasar nie należał do zwolenników przedstawionej wyżej krytyki klasycznego podejścia i propozycji jego modernizacji. Podejście ontologiczne, oparte na opisie bytu za pomocą równoważnych transcendentalnych wyznaczników, wydaje się być dla niego na tyle elementarne, że samo przez się reprezentuje jedyną drogę do prawdziwego poznania:

Tak więc całkowicie elementarny postulat etyki i estetyki prawdy oraz poznania prawdy wynika z uznania faktu, że dopiero te trzy transcendentalne określenia bytu ukazują jego wewnętrzne bogactwo, to znaczy odsłaniają jego prawdę, że zatem dopiero trwała żywa jedność postawy teoretycznej, etycznej i estetycznej może dać prawdziwe poznanie bytu ${ }^{18}$.

Od Tomasza odróżnia Balthasara tutaj tylko zdecydowane i jawne włączenie piękna (estetyki) do kanonu harmonijnie uzupełniających się i pozostających w pełnej równowadze transcendentaliów.

Tischner nalega jednak na zdecydowaną zmianę sposobu myślenia. Potencjalna równoważność transcendentaliów może być pomyślana co najwyżej w jakiejś odległej perspektywie, jako swego rodzaju dopełnienie pewnego abstrakcyjnego ideału, na osiągnięcie którego można 
liczyć jedynie w wieczności. Jeśli chodzi o dramat życia człowieka tu i teraz na tej ziemi, to transcendentalia, które są nieodłączną częścią tego życia, muszą podlegać swoistemu procesowi dramatyzacji:

Istotnym następstwem zmiany punktu widzenia jest szczególne udramatyzowanie transcendentaliów. Być może gdzieś na wyżynach abstrakcji i wieczności transcendentalia pokrywają się, ale doświadczane tak, jak zjawiają się w ludzkim dramacie doczesności, są one w stanie swoistego sporu $^{19}$.

Dla Balthasara taka interpretacja byłaby jednak przesadzona. Z całym respektem wobec różnic zachodzących pomiędzy transcendentaliami oraz autonomiczności ich własnych dziedzin teolog z Bazylei utrzymuje, iż nie da się prowadzić poważnej refleksji metafizycznej, abstrahując od ich fundamentalnej jedności:

Jakkolwiek by się te trzy aspekty i postawy formalnie różniły, jakkolwiek w każdej poważnej metafizyce muszą być zawsze od siebie odróżniane, to jednak od samego początku, a nie dopiero ex post, trzeba uwzględniać ich wspólne korzenie i ich stałe wzajemne przenikanie się, które jest tak ścisłe, że w pewnej mierze o żadnym członie tej triady nie można konkretnie mówić, nie włączając w to dwóch pozostałych $^{20}$.

Tischner z kolei twierdzi, że każda poważna debata o transcendentaliach musi uwzględniać ich charakter dramatyczny, który nie tylko wprowadza pomiędzy nimi ostre podziały, ale czyni je wręcz niejednokrotnie wzajemnie przeciwnymi:

Waśnie dlatego, że transcendentalia są w sporze, człowiek odkrywa, iż jego świat jest światem popękanym i że on sam jest istotą pękniętą, istotnie, a nie tylko przez przypadek, dramatyczną ${ }^{21}$.

20 H. U. von Balthasar, Teologika, t. 1, dz. cyt., s. 30.

21 J. Tischner, Filozofia dramatu, dz. cyt., s. 51. 
Nietrudno sobie jednak wyobrazić, że Balthasar pozostałby niewzruszony także wobec tej argumentacji. W istocie, jak zaznaczyliśmy to na wstępnie, on również świadom jest istnienia paradoksu „walki transcendentaliów", zwłaszcza na polu teologicznym, ale - co ciekawe i wielce znamienne - zjawisko to interpretuje właśnie na korzyść swej tezy o pełnej jedności i równoważności między nimi: „po raz kolejny ujawnia się tu jedność «chwały» $\mathrm{i}$ «dramatyki»"22.

W tym punkcie widać wyraźnie, gdzie przebiega linia podziału pomiędzy poglądami Balthasara i Tischnera w kwestii „walki transcendentaliów". Tischner stoi na stanowisku antropologiczno-egzystencjalnym. Interesuje go przede wszystkim ich rola w konkretnym, zwłaszcza dramatycznym, doświadczeniu człowieka. W ujęciu tym transcendentalia pozostają w ciągłej walce: to, co jawi się jako piękne, może nie być dobre. Prawda może być brutalna. Piękno i prawda stają więc na innym poziomie, a czasem wręcz w opozycji wobec dobra. Balthasar preferuje podejście bardziej abstrakcyjne. Nie stroni od przykładów egzystencjalnych, dostrzegając również ich charakter dramatyczny. Wszystko to wpisuje jednak w głębszą, nadal dynamiczną, ale w pełni zrównoważoną strukturę. Piękno, prawda i dobro to dla niego różne od siebie, ale w pełni równoważne i harmonijnie dopełniające się odsłony jednego i tego samego bytu ${ }^{23}$.

22 H. U. von Balthasar, Theodramatik, Bd. 3, dz. cyt., s. 12 [tł. wł.].

23 Wypada wspomnieć tu o klasyfikacji podejścia do transcendentaliów zaproponowanej przez Marię M. Baranowską: „Wydaje się, że w ostatecznym rachunku u Tischnera transcendentalia funkcjonują nie w sensie klasycznym, Tomaszowym, tylko nowożytnym, Kantowskim. Są warunkami możliwości bytu i niebytu, ludzkiego dramatu uwikłania w zło i dobro, prawdę i kłamstwo, piękno, brzydotę i piękno fałszywe” (M. Baranowska, Piękno płaszczem dobra. Od Plotyna do Stróżewskiego $i$ Tischnera, „Zeszyty Naukowe Centrum Badań im. Edyty Stein” - Fenomen dobra 2015 nr 13/14, s. 71). W tym - nieco uproszczonym, ale niepozbawionym racji - ujęciu można by powiedzieć, że Balthasar jest przedstawicielem klasycznego, Tomaszowego podejścia, Tischner zaś nowożytnego, Kantowskiego, choć pamiętać trzeba, że Balthasar jest tu dużo wierniejszym kontynuatorem Tomasza niż Tischner Kanta. 


\section{Spór o relatywny i absolutny prymat dobra wśród transcendentaliów}

W poprzedniej sekcji mieliśmy okazję przekonać się, co ogólnie dzieli Balthasara i Tischnera w ich spojrzeniu na kwestię transcendentaliów. W obecnej zobaczymy, w czym ta różnica przejawia się konkretnie.

Zanim przejdziemy do analizy różnic, warto podkreślić pewną płaszczyznę wspólną. Obaj myśliciele uwrażliwieni są bowiem na aspekt dramatyczny rozwijanej przez siebie refleksji. Obaj zdają się również zgadzać co do wyjątkowej roli dobra jako transcendentale podstawowego i absolutnie niezbędnego do prowadzenia refleksji dramatycznej ${ }^{24}$. $\mathrm{W}$ podejściu dramatycznym obu autorów dobro wysuwa się zdecydowanie na pierwszy plan. W tym jednak momencie podobieństwa między nimi się kończą. Inną interpretację nadaje temu „pierwszeństwu” dobra Balthasar, a inną Tischner.

Oczywiście różnica ta musi być konsekwencją odmienności ich spojrzenia na ogół problemu dotyczącego transcendentaliów. Balthasar kwestię prymatu dobra w teodramatyce będzie musiał pogodzić z teorią pełnej równorzędności wszystkich transcendentaliów. Tischner wykorzysta kontekst dramatyczny, by jeszcze wyraźniej wyeksponować różnicę, jaka rysuje się między dobrem a pozostałymi transcendentaliami.

\subsection{Stanowisko Balthasara}

Balthasar stoi na stanowisku, że każde transcendentale zasługuje na taką samą uwagę i każdemu z nich należy poświęcić głębokie studium.

24 Widać to w konstrukcji ich myśli (teo)dramatycznej. Jak wspomnieliśmy już w sekcji wstępnej, Balthasar, tworząc swą Trylogię, opiera Chwałę, czyli Estetykę teologiczną na pięknie, Teologikę na prawdzie, a Teodramatykę właśnie na dobru: „To, czego Bóg dokonuje na człowieku, właśnie nie jest dwuznaczne, ale jest po prostu dobrem. W teodramatyce chodzi o dobro" (H. U. von Balthasar, Teodramatyka, t. 1: Prolegomena, tłum. M. Mijalska, M. Rodkiewicz, W. Szymona, Kraków 2005, s. 18). Tischner zaś całą swoją filozofię dramatu wyprowadza z zasady agatologicznej: „nie byłoby dramaturgii bliskości i oddalenia, samodzielności i daru, gdyby u korzeni całej dramaturgii nie leżało uczestnictwo w Dobru" (J. Tischner, Spór o istnienie człowieka, Kraków 2011, s. 398). 
Można powiedzieć, że tak zrodziła się Trylogia, której poszczególne trzy części zakotwiczone są w trzech podstawowych transcendentaliach.

Kiedy czyta się pierwszą część Trylogii, czyli Chwałę, zwaną też Estetyka teologiczna, można odnieść chwilowe wrażenie, jakoby Balthasar wynosił w tej części swojego dzieła piękno ponad pozostałe transcendentalia. Zdają się to sugerować słowa samego autora, tak opisującego transcendentale, z którego wyrasta jego Estetyka:

To słowo to piękno; dla nas będzie ono pierwszym słowem. Piękno jest ostatnią rzeczywistością, na którą może ważyć się myślący rozum, ponieważ jako niepojęty blask otacza ono podwójną gwiazdę prawdy i dobra oraz ich nierozerwalne odniesienie do siebie ${ }^{25}$.

Niemniej jednak, jeśli zerkniemy do Teodramatyki, zacznie wydawać się, że perspektywa ulega zmianie i na pierwszy plan wysuwa się dobro: „w każdym razie owo dokonane dobro nie daje się dostrzec w czystej «estetyce» ani dowieść i wykazać w czystej «logice»" ${ }^{26}$.

Kiedy zaś zajrzymy do trzeciej części Balthasarowskiej Trylogii, bez trudu zauważymy, że na pierwszy plan zdecydowanie wysuwa się w niej prawda. Podobnie w Epilogu, gdzie znajdziemy fragmenty, które do tego stopnia podkreślają wagę prawdy, że tym razem to ona zaczyna jawić się jako „to, co pierwsze”, „punkt szczytowy” i „dopełnienie” refleksji nad transcendentaliami:

Tym samym widać wyraźnie, w jakim sensie „prawda” stanowi dopełnienie „piękna” i „dobra” i w jakim to, co ostatnie, musi być zarazem tym, co pierwsze. Patrząc z perspektywy ewolucyjnej, prawda może w płaszczyźnie wewnątrzziemskiej

25 H. U. von Balthasar, Chwała. Estetyka teologiczna, t. 1: Kontemplacja postaci, tłum. E Marszał, J. Zakrzewski, Kraków 2008, s. 16.

26 H. U. von Balthasar, Teodramatyka, Bd. 1, dz. cyt., s. 19. Podobny „tymczasowy” prymat dobra występuje u Balthasara w tej części Epilogu, w którym stara się on przybliżyć czytelnikowi ideę teodramatu intratrynitarnego: „Przy czym dominuje teraz «dobro» - ukazywanie siebie i wypowiadanie siebie osiągają swój punkt szczytowy w absolutnym dawaniu siebie” (H. U. von Balthasar, Epilog, dz. cyt., s. 68). 
wystąpić dopiero w punkcie szczytowym naturalnego rozwoju - tam, gdzie istnienie, życie, świadomość pogłębiły się i osiągnęły stopień samoświadomości ${ }^{27}$.

Wszystko to jednak nie zaprzecza logicznej spójności myśli Balthasara, lecz wręcz ją potwierdza. W ujęciu szwajcarskiego teologa, z absolutnego punktu widzenia, wszystkie transcendentalia są między sobą równe. Dla każdego z nich można jednak znaleźć taki obszar lub taki aspekt rozpatrywanego zagadnienia, w którym dane transcendentale uzyskuje prymat relatywny. Kiedy zmieniamy obszar lub aspekt zainteresowania, naturalne jest, że prymat relatywny przypadnie wówczas w rozważaniach innemu transcendentale.

Jest to zresztą podejście typowe dla metody fenomenologicznej. $\mathrm{W}$ metodzie tej ten sam obiekt opisuje się, patrząc na niego z różnych stron lub perspektyw. W danej chwili na pierwszy plan wysuwa się jedna tylko z obserwowanych stron i związany z nią aspekt badań (np. dane transcendentale) uzyskuje status prymatu relatywnego. Wystarczy jednak na ten sam obiekt spojrzeć $z$ innej strony lub perspektywy i wówczas relatywny prymat uzyska inny aspekt rozważanego zagadnienia.

Dopiero po pełnym oglądzie i integralnym rozpatrzeniu wszystkich aspektów można pokusić się o werdykt, czy są one rzeczywiście równoważne, czy też któryś z nich wyróżnia się w sposób szczególny, nie tylko relatywnie, ale także w ujęciu absolutnym. Jak się za chwilę przekonamy, w tym właśnie osądzie końcowym leżeć będzie podstawowa różnica między poglądami Balthasara i Tischnera.

\subsection{Stanowisko Tischnera}

Tischner staje na stanowisku, że dobro zachowuje wśród transcendentaliów prymat nie tylko relatywny, ale również absolutny. Jak już wcześniej wspomnieliśmy, zapożycza on to przekonanie od Lévinasa. Zasada agatologiczna zaczyna stopniowo dominować w myśli Tischnerowskiej do tego stopnia, że mówiąc o pięknie czy o prawdzie, nie czuje on 
konieczności wychodzenia poza płaszczyznę ontologiczną. Kiedy jednak mowa jest o dobru, myśli on o czymś więcej niż o samym bycie - odczuwa silną potrzebę wzniesienia się na wyższy od ontologicznego poziom, który z upodobaniem określa jako agatologiczny.

By zilustrować tę Tischnerowską intuicję, warto posłużyć się następującym przykładem. Kamień w górach czy kolor nieba mogą być piękne; twierdzenia Talesa i Pitagorasa są prawdziwe; żadne z nich nie jest jednak ani dobre, ani złe - są agatologicznie obojętne - w tym sensie, że żadne $\mathrm{z}$ nich nie jest $\mathrm{w}$ stanie wykonać, samo z siebie, czegoś dobrego lub złego. Dla Tischnera bowiem dobro musi być związane z jakimś świadomym i wolnym, czyli osobowym, działaniem: „Być dobrym znaczy: czynić to, co dobre"28.

Refleksja nad dobrem musi dotyczyć działania osób i zazwyczaj wiąże się z rozgrywającym się między nimi dramatem. Międzyosobowy dramat to dla Tischnera środowisko naturalne, w którym należy prowadzić badania nad dobrem:

Jak można pojąć dobro? Można je pojąć jedynie wnikając w głąb rozlicznych wątków dramatycznych, jakie zawiązuje między ludźmi. U podstaw wszystkich wątków tkwi to jedno: ziarno dobroci obudzonej w człowieku przez dobro ${ }^{29}$.

Uwydatnia się tu aspekt dramatyczny podejścia Tischnerowskiego, podobnie zresztą jak było u Balthasara. Różnica polega na tym, że dla krakowskiego myśliciela pomiędzy pięknem i prawdą a dobrem zachodzi potężna różnica jakościowa. Pierwsze dwa mogą odnosić się nie tylko do osób dramatu, ale także do elementów nieożywionej sceny, podczas gdy dobro nabiera statusu absolutnie wyjątkowego: zarezerwowane jest jedynie dla rzeczywistości osobowych, gdzie mamy do czynienia ze świadomym działaniem, które wymaga podmiotu dysponującego wolnością. Absolutna wyjątkowość pozycji dobra na tle pozostałych transcendentaliów uwidacznia się dodatkowo w twierdzeniu Tischnera,

29 J. Tischner, Filozofia dramatu, dz. cyt., s. 58. 
że refleksja nad dobrem wymaga już nie tylko wzbicia się na pewien wyższy poziom refleksji od poziomu obiektywno-ontologicznego, lecz także zastosowania innej logiki: „logika dobra i logika bytu to oddzielne logiki" ${ }^{30}$.

\subsection{Konfrontacja obu stanowisk}

Jak ustaliliśmy w poprzednich rozważaniach, u Tischnera wyjątkowa pozycja dobra wśród transcendentaliów wynika bezpośrednio z rozróżnienia dwóch podstawowych poziomów: agatologicznego i ontologicznego. Balthasar zdecydowanie sprzeciwiał się takiemu rozróżnieniu. Jego zdaniem refleksja agatologiczna, również ta biorąca pod uwagę relacje osobowe, takie jak relacja miłości zachodząca pomiędzy osobami dramatu, nie musi być oddzielona od poziomu ontologicznego. Zdaniem szwajcarskiego teologa jest wręcz przeciwnie: to właśnie na przykładzie międzyosobowej relacji miłości, jak w soczewce, ogniskuje się pełna jedność poziomu ontologicznego, agatologicznego, logicznego i estetycznego:

Człowiek istnieje tylko w dialogu z bliźnim. Dziecko poprzez miłość i uśmiech matki zyskuje świadomość samego siebie. W tym spotkaniu otwiera się przed nim horyzont całego nieskończonego Bytu i ukazuje mu cztery rzeczy: 1. Że w miłości stanowi ,jedno" ze swoją matką, mimo iż jest jej przeciwstawione, że więc wszelkie bycie stanowi „jedno”. 2. Że miłość ta jest „dobra”: „dobry” jest więc cały Byt. 3. Że miłość ta jest „prawdziwa”, „prawdziwy” jest zatem cały Byt. 4. Że miłość ta budzi radość, cały Byt jest więc „piękny”31.

Nietrudno sobie wyobrazić, że Tischner zgodziłby się z tym wszystkim pod jednym warunkiem: że słowo „Byt” zastąpimy słowem „Dobro”. Szukał więc koronnego argumentu przemawiającego za tezą o absolutnym prymacie dobra. I tu, co ciekawe, mimo że większość swoich badań

31 H. U. von Balthasar, O moim dziele, tłum. M. Urban, Kraków 2004, s. 81. 
zamknął w sferze antropologicznej, poszukując argumentów za absolutnym prymatem dobra, dotarł do zagadnienia Dobra absolutnego, czyli Boga. Tischner wolał wręcz posługiwać się terminem „Dobro” (pisanym z premedytacją z dużej litery) zamiast terminem „Bóg”" ${ }^{2}$, by podkreślić, że to właśnie to transcendentale, a nie inne, w najpełniejszy sposób opisuje to, co jest „Absolutne”, wobec czego wszystkie inne kategorie mają charakter relatywny:

Bóg jest absolutnym Dobrem. Nie tylko ma udział w dobru, ale jest Dobrem. Co to znaczy „być Dobrem”? Być Dobrem - Dobrem absolutnym - znaczy: być „niezależnym” od dobroci wszelkich innych dóbr, które w obliczu Dobra absolutnego muszą nabrać charakteru relatywnego ${ }^{33}$.

Dobro jest więc jedyną kategorią, która u Tischnera „sięga absolutu”. Oczywiście to Dobro absolutne charakteryzuje się również pięknem i prawdą, ale dla krakowskiego myśliciela są to już charakterystyki drugorzędne, relatywne i niewystarczające.

Różnica między Tischnerem i Balthasarem polega więc na tym, iż Balthasar nigdy nie przyznałby dobru tak wyróżnionego statusu prymatu absolutnego. Owszem, jak widzieliśmy już wyżej, również i on wskazywał na wyjątkową rolę dobra, ale zawsze w ramach jakiegoś ograniczonego obszaru rozważań. U Balthasara, w przypadku dobra, można, w pewnych sytuacjach, mówić o statusie prymatu relatywnego, który w żaden sposób nie może naruszyć nadrzędnej, dla niego, zasady równoważności wszystkich transcendentaliów.

32 Tischner utożsamiał pojęcie Boga z pojęciem najwyższego Dobra (por. J. Tischner, Filozofia człowieka dla duszpasterzy i artystów, Kraków 1991, s. 127). Tym sposobem doszedł on m.in. do swojej słynnej agatologicznej modyfikacji ontologicznego „dowodu” Anzelma: „Spróbujmy przyjąć inne założenie i uznać, że tym, «ponad co niczego większego nie można pomyśleć», jest Dobro jako transcendens. Co osiągamy? Wtedy wykraczamy poza otologię i przechodzimy z poziomu «logiki bytu» na poziom «dramaturgii dobra»" (J. Tischner, Spór o istnienie człowieka, dz. cyt., s. 315).

${ }^{33}$ J. Tischner, Spór o istnienie człowieka, dz. cyt., s. 317. Ten szczegół chyba najdobitniej przedstawia różnicę między Balthasarem a Tischnerem: kiedy Balthasar (w rozważaniach filozoficznych) myślał o Bogu, pisał „Byt”; kiedy Tischner myślał o Bogu, pisał „Dobro”. 


\section{Spostrzeżenia i wnioski}

Podsumowując powyższe rozważania, należy stwierdzić, że w kwestii roli dobra wśród transcendentaliów Balthasar i Tischner reprezentują ogólnie zbliżone, niemniej jednak odmienne w szczegółach stanowiska. To, co ich łączy, to wspólne dogłębne przekonanie o kluczowym znaczeniu dobra w refleksji nad dramatem życia ludzkiego. To, co ich dzieli, to pogląd dotyczący statusu (tj. prymatu absolutnego lub relatywnego) dobra wśród pozostałych transcendentaliów.

Między Balthasarem a Tischnerem zarysowuje się tu pewien spór. Nie jest naszym celem pytać teraz - a tym bardziej rozstrzygać - kto ma rację. Wyprowadzimy jednakże ze zgromadzonego materiału pewne spostrzeżenia i wnioski, zostawiając czytelnikowi pole do oceny własnej.

Zaczniemy od pewnej obserwacji dotyczącej poglądów Balthasara. Na pierwszy rzut oka jawią się one jako dużo bardziej wyważone i spójne $\mathrm{z}$ dotychczasową tradycją filozoficzną $\mathrm{w}$ porównaniu $\mathrm{z}$ - trzeba przyznać - dość radykalnymi i niestandardowymi tezami Tischnera ${ }^{34}$.

Balthasar ma jednak pewien problem $\mathrm{z}$ zachowaniem spójności wewnętrznej. Z jednej strony stanowczo opowiada się za zasadą jedności i równoważności transcendentaliów, z drugiej - wyraźnie stara się wyróżnić i podkreślić wyjątkowość swojej teodramatycznej propozycji. Dochodzi do tego, że na początku drugiego tomu Teodramatyki, rzucając retrospektywne spojrzenie na tom pierwszy, w którym przedstawił swą nowatorską propozycję, nie waha się nie tylko stwierdzić, że podejście to przewyższa podejścia klasyczne (zwane przez niego „epickimi” i „lirycznymi”), lecz idzie jeszcze dalej, by nadać swemu przedsięwzięciu status absolutnego, nieosiągalnego wręcz szczytu, do którego pozostałe podejścia mogą, co najwyżej, próbować dążyć:

W ten sposób opuściliśmy płaszczyznę teologii epickiej (nie mówiąc o lirycznej) i weszliśmy na nową, szerszą płaszczyznę teodramatyki; umożliwia to nam spojrzenie

34 Brak spójności z tradycją może być wysuwany jako największy mankament podejścia Tischnerowskiego. 
wstecz na wzmiankowane na początku Prolegomen dziewięć tendencji dzisiejszej teologii, o których powiedzieliśmy, że mają punkt zbieżny w teodramatyce, ku niemu wprawdzie zmierzają, ale którego nie mogą osiągnąć ${ }^{35}$.

By móc podtrzymać twierdzenie o tak wyjątkowym statusie swej teodramatycznej propozycji, Balthasar powinien - naszym zdaniem - zmierzyć się z pytaniem: jak to możliwe, że teodramatyka - wyraźnie oparta na dobru jako jednym $z$ transcendentaliów - zajmuje tak wyabsolutyzowane miejsce spośród innych podejść, podczas gdy leżące u jej podstaw transcendentale (dobro) żadnym szczególnym statusem pośród innych transcendentaliów cieszyć się nie może?

Tischner obrał drogę całkowicie przeciwną: agatologii nadał status absolutnie nadrzędny i wyjątkowy, ale opartej na niej swojej własnej filozofii dramatu absolutyzować wobec innych podejść filozoficznych bynajmniej nie próbował.

W przypadku Tischnera warto zwrócić uwagę na inny wątek. Mianowicie, wiemy już, że szukając argumentów za nadrzędnym charakterem dobra, dotarł on do idei Boga jako Dobra. Konfrontując to podejście z szeroko pojętą chrześcijańską tradycją filozoficzno-teologiczną, orzekającą, iż Bóg jest Piękny, Prawdziwy i Dobry, a nawet dużo więcej, tj. że Bóg jest Pięknem, Prawdą i Dobrem, nie widać żadnego powodu, dla którego dobro miałoby być faworyzowane. Spróbujmy jednak zadać pytanie: Dlaczego (chrześcijański) Bóg zbawia człowieka? Czy dlatego, że jest Piękny (Pięknem)? Czy dlatego, że jest Prawdziwy (Prawdą)? Oczywiście dałoby się znaleźć niejeden argument, by udzielić tu odpowiedzi twierdzących, choć nietrudno znaleźć i argumenty przeciwne. Bóg Piękny (będący tylko Pięknem) mógłby być całkowicie obojętny na dramat człowieka i mógłby nie zawracać sobie głowy zbawianiem kogokolwiek. Bóg Prawdziwy (będący tylko Prawdą) mógłby znaleźć więcej argumentów, by człowieka potępić, niż by go zbawić. Niepodważalna i pełna wydaje się być tylko jedna odpowiedź: Bóg zbawia człowieka

35 H. U. von Balthasar, Teodramatyka, t. 2/1: Osoby dramatu. Człowiek w Bogu, tłum. W. Szymona, Kraków 2006, s. 57. 
dlatego, że jest Dobry ${ }^{36}$. Tylko Bóg Dobry zada sobie trud, by włączyć się w dramat egzystencji człowieka, w dramat jego upadku i potrzeby zbawienia i podjąć wobec niego działanie zbawcze.

Dobro w sposób naturalny uzyskuje tu wyższy, bardziej uniwersalny status od pozostałych transcendentaliów. Tischner przedstawionego tu przez nas wniosku explicite nie sformułował, ale można powiedzieć, że ilustruje on „w jego duchu” ideę nadrzędnego charakteru dobra, o której wyeksplikowanie krakowski myśliciel tak bardzo zabiegał.

\section{Bibliografia}

Balthasar H. U. von, Herrlichkeit. Eine theologische Ästhetik, Bd. 1-3, Einsiedeln 19611969 (Chwała. Estetyka teologiczna, t. 1-3, tłum. E Marszał, J. Zakrzewski, Kraków 2007-2013).

Balthasar H. U. von, Theodramatik, Bd. 1-4, Einsiedeln 1973-1983 (Teodramatyka, t. 1-2, tłum. M. Mijalska, M. Rodkiewicz, W. Szymona, Kraków 2005-2006).

Balthasar H. U. von, Theologik, Bd. 1-3, Einsiedeln 1985-1987 (Teologika, t. 1-3, tłum. J. Zychowicz, Kraków 2004-2005).

Balthasar H. U. von, Epilog, Einsiedeln 1987 (Epilog, tłum. J. Zychowicz, Kraków 2010). Balthasar H. U. von, Zu seinem Werk, Einsiedeln 2000 (O moim dziele, tłum. M. Urban, Kraków 2004).

Balthasar H. U. von, Theologie und Heiligkeit, w: Verbum Caro. Skizzen zur Theologie, Bd. 1, Einsiedeln 1990, s. 195-225.

36 Analogicznie (i bardziej filozoficznie) można by zapytać nie tyle o Boga, ile o sam akt zbawczy: Czy akt zbawczy jest piękny? Czy akt zbawczy jest prawdziwy? I znowu można by znaleźć niejeden argument „za”, choć nietrudno znaleźć też argumenty przeciw. Akt zbawczy w chrześcijaństwie dokonał się w konkretnym wydarzeniu męki i śmierci krzyżowej Chrystusa. Czy można powiedzieć, że śmierć Chrystusa na krzyżu była piękna? Dla każdego chrześcijanina akt zbawczy, który się wówczas dokonał, jest niewątpliwie prawdziwy, ale już dla kilku miliardów ludzi, niebędących chrześcijanami, akt ten prawdziwy bynajmniej nie jest. Uniwersalne jest tylko dobro aktu zbawczego. Jeżeli bowiem zbawienie jest uratowaniem człowieka od zła (zguby wiecznej), to z czysto formalno-logicznego powodu każdy człowiek o zdrowych zmysłach (niezależnie od swoich poglądów estetycznych i religijnych) musi przyznać, iż akt zbawczy, czyli akt uwolnienia kogoś od zła, musi być aktem dobrym. Dobro, jako jedyne spośród transcendentaliów, nabiera w tej perspektywie charakteru absolutnie uniwersalnego. 
Baranowska M., Piękno płaszczem dobra. Od Plotyna do Stróżewskiego i Tischnera, „Zeszyty Naukowe Centrum Badań im. Edyty Stein” - Fenomen dobra 2015 nr 13/14, s. $66-80$.

Bobko A., Myślenie wobec zła, Kraków-Rzeszów 2007.

Kiełbasa J., Pierwsze i najpowszechniejsze: jedność, prawda, dobro i inne transcendentalia w metafizyce św. Tomasza z Akwinu, „Przegląd Tomistyczny” 19 (2013), s. 251-280.

O’Donnell J., Klucz do teologii Hansa Ursa von Balthasara, Kraków 2005.

Saint-Pierre M., Beauté, bonté, vérité, chez Hans Urs von Balthasar, Paris 1998.

La teologia del XX secolo: un bilancio, t. 1: Prospettive storiche, a cura di G. Canobbio, P. Coda, Roma 2003.

Tischner J., Filozofia dramatu, Kraków 2012.

Tischner J., Spór o istnienie człowieka, Kraków 2011.

Tischner J., Filozofia człowieka dla duszpasterzy i artystów, Kraków 1991.

\section{Abstrakt}

\section{Agatologiczne implikacje} paradoksu „walki transcendentaliów” u Hansa Ursa von Balthasara i Józefa Tischnera

W niniejszym artykule rozpatrujemy problem równoważności transcendentaliów: piękna, prawdy i dobra, w ujęciu dwóch znakomitych myślicieli XX wieku: H. U. von Balthasara i J. Tischnera. Opierając się na konfrontacji ich refleksji, wprowadzamy pojęcie paradoksu „walki transcendentaliów” i analizujemy stanowiska filozoficzne, jakie zajmują oni wobec tego zagadnienia. Uzyskane wyniki badań, dotyczące ogółu transcendentaliów, konkretyzujemy następnie na gruncie agatologicznym, na którym najwyraźniej zarysowują się podobieństwa i różnice w poglądach obu autorów. Wspólną płaszczyzną dla Balthasara i Tischnera okazuje się być uznanie dobra jako transcendentale fundamentalnego dla rozwijania refleksji (teo)dramatycznej. Podstawowa różnica ujawnia się w ich postrzeganiu relacji dobra do pozostałych transcendentaliów. Tischner opowiada się za absolutnym prymatem dobra wśród transcendentaliów, Balthasar dopuszcza w tym przypadku jedynie prymat relatywny. W końcowej sekcji pracy zwracamy uwagę na pewne mankamenty obu podejść i proponujemy soteriologiczno-antropologiczny przykład ilustrujący zasadność podejścia Tischnerowskiego. 


\section{Słowa kluczowe}

transcendentalia, agatologia, prymat dobra, Balthasar, Tischner

\section{Abstract \\ Agathological implications of the paradox of the "fight of transcendentals" in Hans Urs von Balthasar and Józef Tischner}

In this article, we consider the problem of the equivalence of transcendentals: beauty, truth and good, in the perspective of two great thinkers of the twentieth century: H. U. von Balthasar and J. Tischner. Based on the confrontation of their reflections, we introduce the concept of the paradox of the "strugle of transcendentals" and we analyze the philosophical positions they occupy in this matter. The obtained research results, concerning all transcendentals, are then concretized on the agathological ground, where the similarities and differences in views of both authors are apparent. A common ground for Balthasar and Tischner consists in the recognition of good as a fundamental transcendentale in the development of (theo)dramatic reflection. The basic difference is revealed in their perception of the relation of good to other transcendentals. Tischner is in favor of the absolute primacy of good among all transcendentals, while Balthasar admits only a relative primacy in this case. In the final section of the work we indicate some shortcomings of both approaches and we propose a soteriological-anthropological example illustrating the validity of tischnerian approach.

\section{Keywords}

transcendentals, agathology, primacy of good, Balthasar, Tischner 